\title{
ESTABLISHING THE REFERENCE RANGE FORT LYMPHOCYTES SUBPOPULATIONS IN ADULTS AND CHILDREN FROM BRAZIL
}

\author{
Alex José Leite TORRES(1), Ana Luiza Dias ANGELO(1), Márcio Oliveira SILVA(1), Milena de Carvalho BASTOS(1), Denise Ferreira de SOUZA(2), \\ Lílian Amaral INOCÊNCIO(2), José Alexandre Rodrigues de LEMOS(3), Ruy S. JUNIOR(4), Andréa Cauduro de CASTRO(5), \\ Patrícia Vianna Bonnini PALMA(6), Loredana CECI(7), Eduardo Martins NETTO(1) \& Carlos BRITES(1)
}

\begin{abstract}
SUMMARY
In Brazil, the existing reference values for T-lymphocytes subsets are based on data originated in other countries. There is no local information on normal variation for these parameters in Brazilian adults and children. We evaluated the normal variation found in blood donors from five large Brazilian cities, in different regions, and in children living in Salvador, and Rio de Janeiro. All samples were processed by flow cytometry. The results were analyzed according to region, gender, and lifestyle of blood donors. A total of 641 adults (63\% males), and 280 children (58\% males) were involved in the study. The absolute CD3+, and CD4+ cells count were significantly higher for females (adults and children). Higher CD4+ cell count in adults was associated with smoking, while higher CD8+ count was found among female children. Higher counts, for all T-cells subsets, were detected in blood donors from southeast / south regions while those living in the northern region had the lowest values. Individuals from midwestern and northeastern regions had an intermediate count for all these cells subsets. However, these differences did not reach statistical significance. In Brazil, gender and smoking, were the main determinants of differences in T-lymphocytes reference values.
\end{abstract}

KEYWORDS: CD4; CD8; Blood donors; Reference values; Brazil.

\section{INTRODUCTION}

Absolute white blood cell count and their subsets play a major role in both cellular and humoral immunity. CD4+ T cells have a central role in the generation of a proper immune response, especially in cellmediated processes. These cells are responsible for three important steps in the immune response: activation, regulation and memory ${ }^{28}$. The CD4+ T-lymphocytes are the main target for HIV-1, and the infection by this virus promotes a progressive depletion of this T-cells subset, causing AIDS $^{4}$. The quantification of these lymphocytes is an important tool in monitoring HIV-1 infection, as well as other immune deficiencies caused by decreased number of CD4+ cells ${ }^{2,7,10}$. It is used to define the optimal moment to start antiretroviral therapy and/or prophylaxis of opportunistic infections $\mathrm{s}^{13,30}$. The available evidence suggest that variations in the CD4+ cell count may depend on certain factors like nutrition, environment, and genetics ${ }^{14,22,26}$.

In children, the number of circulating $\mathrm{T}$ cells increases from midgestation up to the age of six months. This peak is followed by a gradual decline until adult levels are reached by late childhood ${ }^{27}$. As a result of the age-related changes in the absolute lymphocyte numbers, and thus, CD4+ count, the Centers for Disease Control and Prevention (CDC) classifies children into immune categories using CD4+, by using a system based on specific age groups ${ }^{20}$.

Several studies have shown significant variations of CD4 T cells within different African populations, in comparison with the values established for Europe and North America ${ }^{19,25,34}$. Brazil is a country with continental dimensions, and a wide ethnical variation, with different climates, and nutritional habits. In a previous report we detected significant differences in CD4 T cells count for blood donors from the cities of Belém and Salvador ${ }^{29}$. This led us to evaluate blood samples originated from others regions and also to include children from two states. In this work we present the results of a comparison of T-lymphocytes count between blood donors from five cities of different Brazilian regions, and children from two different cities.

\section{METHODS}

Study design, setting and population: A cross sectional study was conducted in blood centers of five capitals of different states, each one representing a geographic region: Salvador (Bahia State, Northeast region), Belém (Pará State, North region), Ribeirão Preto (São Paulo State, Southeast region), Goiânia (Goiás State, Midwest region), and

(1) Federal University of Bahia, Salvador, BA, Brazil.

(2) AIDS and SDT National Program, Brazilian Ministry of Health

(3) Hematology and Hemotherapy Center from state of Pará, HEMOPA Foundation, Federal University of Pará, Belém, PA, Brazil.

(4) Central Laboratory from Goiás.

(5) Hospital Nossa Senhora da Conceição, Rio Grande do Sul.

(6) Hematology, Hemotherapy Center Foundation from Ribeirão Preto, SP, Brazil.

(7) Infectious Diseases Laboratory, HSE from Rio de Janeiro, RJ, Brazil.

Financial Support: AIDS and STD National Program from Brazilian Ministry of Healthy.

Correspondence to: ajltorres@gmail.com 


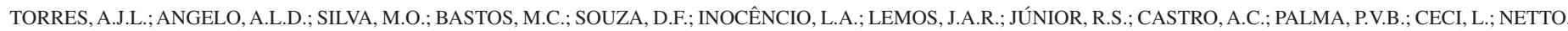
E.M. \& BRITES, C. - Establishing the reference range for T lymphocytes subpopulations in adults and children from Brazil. Rev. Inst. Med. Trop. Sao Paulo, 55(5): 323-8, 2013.

Porto Alegre (Rio Grande do Sul State, South region). The children involved in the study were originated from Rio de Janeiro (Rio de Janeiro State) and Salvador (Bahia). The centers participants in this study were Hematology and Hemotherapy Centers from Bahia, Pará and São Paulo, Central Laboratory of Goiás State, Hospital Nossa Senhora da Conceição (Rio Grande do Sul), and Federal University of Rio de Janeiro.

We included 645 adult donors and 280 healthy children 280 volunteers (148 from Bahia and 132 from Rio de Janeiro).

Study subjects: Study subjects were healthy adults and infants. Adults were eligible if older than 18 years, and agreed to participate in the study. The infants selected for this study were between two and six years old. Blood was collected in ethylenediaminetetraacetic acid (EDTA) tubes. The same samples were used for serological tests and immunophenotyping. Samples were collected in the morning from 9.00 $\mathrm{AM}$ to 12.00 noon, kept at room temperature and analyzed in the same day.

All adults provided a written informed consent. For children, a written consent was obtained from their legal guardians. Adults subjects and children guardians were interviewed, using a structured questionnaire with information on demographics, and lifestyle (smoking, alcohol consumption, and stress level, measured by daily routine sleep time), and screened for symptoms such as fever, cough and weight loss to rule out any recent and/or current infections.

The following categories were excluded: pregnant women, patients receiving medical treatment, individuals with history of recent or current morbid conditions, and individuals who tested positive for HIV, HTLV, $\mathrm{HCV}, \mathrm{HBV}$ and Syphilis antibodies.

\section{Laboratory procedure}

Serological tests: Serological tests for HIV, HTLV, HCV, HBV and syphilis were done using ELISA antibody tests (Vironostika, Biomerieux). Patients that presented positive or inconclusive results were excluded of the study.

T cells counts by Immunophenotyping: T cells subpopulations were analyzed by using a FACSCalibur flow cytometer (Becton Dickinson Immunocytometry Systems, San Jose, Calif.). In brief, $20 \mu \mathrm{L}$ of Multitest (CD3/CD8/CD45/CD4 - Becton Dickinson Immunocytometry Systems, San Jose, Calif.). Monoclonal antibodies were additioned in Trucount tubes containing reference beads (Becton Dickinson Immunocytometry
Systems, San Jose, Calif.). $50 \mu \mathrm{L}$ whole blood was mixed and incubated at room temperature for $20 \mathrm{~min}$ in dark. Red blood cells were then lysed by adding $450 \mu \mathrm{L}$ of fluorescence-activated cell sorter lysing solution (Becton Dickinson Immunocytometry Systems). The tubes were incubated at room temperature for $20 \mathrm{~min}$, acquired and analyzed with the Multiset software (Becton Dickinson Immunocytometry Systems) within six hours.

Data management and Statistical analysis: Completed questionnaires were coded by numbers and patient's initials. The data was then transferred to SPSS version 13 for analysis. Chi-square test was used for categorical variables. We calculated means and Standard Deviation, 2.5 ${ }^{\text {th }}$ $97.5^{\text {th }}$ percentile for median and odds ratio (OR) with $95 \%$ confidence intervals (CI) were used. Comparison between the continuous variables was performed by ANOVA or Kruskal-Wallis test.

Ethical considerations: The protocol was approved by the Ethical Committee from Maternidade Climério de Oliveira Hospital, Federal University of Bahia. Informed consent was obtained from the volunteers or from guardians (children) prior to enrolment.

\section{RESULTS}

Characteristics of study's participants: A total of 641 blood donors and 280 children were included in the study. Most of adults (63\%) were male, with a mean age of 33 years (Interquartile range $19 \pm 56$ ). Fifty-nine donors (9\%) declared smoking, 210 subjects (32.5\%) informed to drink alcohol three or more days per week, and $259(40 \%)$ declared a routine sleep time shorter than eight hour/day. Gender was equally distributed for the children involved in the study, with $51 \%$ of males. For this group, the age varied from two to six years.

T cells values and gender: The overall results for the T-cells subsets values are showed in Table 1. Adults females had higher mean absolute lymphocytes counts, higher mean absolute CD3 T cells, and higher mean absolute CD4 T cells than adults males, ( $p<0.001$ for all comparisons). Table 2 displays these findings.

T lymphocytes values according to lifestyle: We didn't find any difference for the $\mathrm{T}$ lymphocytes absolute values when stratifying individuals by alcohol intake and stress level. There was an association between smoking and higher CD4+ cells count (1112 vs. 972 cells $/ \mu \mathrm{L}$, for smokers and non-smokers, respectively, $p<0.01)$. Regarding stress level we found a significant difference for the CD3+ and CD4+ T lymphocytes relative subsets (Table 3 ).

Table 1

Median and mean for T subpopulations cells

\begin{tabular}{|c|c|c|c|c|}
\hline $\begin{array}{l}\text { Parameter } \\
\mathrm{N}=925 \text { (Adults and Children) }\end{array}$ & $\begin{array}{c}\text { Adults } \\
\text { Median }(\mathrm{N}=641) \\
\text { Cells } / \mu \mathrm{L}\end{array}$ & $\begin{array}{c}\text { Adults } \\
\text { 2.5th-97.5th percentile } \\
\text { Cells } / \mu \mathrm{L}\end{array}$ & $\begin{array}{c}\text { Children } \\
\text { Median }(\mathrm{N}=284) \\
\text { Cells } / \mu \mathrm{L}\end{array}$ & $\begin{array}{c}\text { Children } \\
2.5^{\text {th }}-97.5^{\text {th }} \text { percentile } \\
\text { Cells } / \mu \mathrm{L}\end{array}$ \\
\hline T CD4+ lymphocytes & 931 & $540-1731$ & 1652 & $803-4291$ \\
\hline T CD8+ lymphocytes & 541 & $263-1189$ & 1065 & $470-3116$ \\
\hline T CD3+ lymphocytes & 1585 & $1025-2904$ & 2996 & $1440-6350$ \\
\hline Total lymphocytes CD45+ & 2445 & $1257-4104$ & 4658 & $2372-7753$ \\
\hline
\end{tabular}




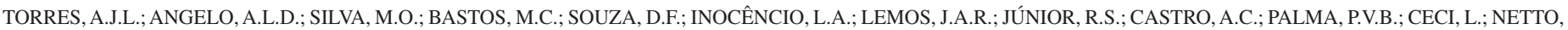
E.M. \& BRITES, C. - Establishing the reference range for T lymphocytes subpopulations in adults and children from Brazil. Rev. Inst. Med. Trop. Sao Paulo, 55(5): 323-8, 2013.

Table 2

Median absolute values for T lymphocytes subsets in adults and children, according to gender and lifestyle

\begin{tabular}{|c|c|c|c|c|}
\hline Parameters & $\mathrm{N}$ & $\begin{array}{l}\text { T CD4 + } \\
\text { Cells/ } \mu \mathrm{L}\end{array}$ & $\begin{array}{l}\text { T CD8 + } \\
\text { Cells/ } \mu \mathrm{L}\end{array}$ & $\begin{array}{l}\text { T CD3 }+ \\
\text { Cells } / \mu \mathrm{L}\end{array}$ \\
\hline Males (Adults) & 403 & 965 & 582 & 1633 \\
\hline Females (Adults) & 238 & $1071^{*}$ & 586 & $1742 *$ \\
\hline Males (Children) & 164 & 1480 & 933 & 2590 \\
\hline Females (Children) & 120 & $2207 *$ & $1407 *$ & $3815^{*}$ \\
\hline Smokers & 55 & 1112 & 578 & 1765 \\
\hline No smokers & 586 & $972 *$ & 579 & 1641 \\
\hline Stress & 259 & 1004 & 591 & 1680 \\
\hline No stress & 382 & 972 & 559 & 1627 \\
\hline Alcohol & 210 & 931 & 579 & 1598 \\
\hline No alcohol & 431 & 1013 & 582 & 1683 \\
\hline
\end{tabular}

$* p<0.01$ for the comparison between groups.

Table 3

Mean percentage values for $\mathrm{T}$ lymphocytes according to gender, age and behavioral characteristics of studied populations

\begin{tabular}{lccc}
\hline $\begin{array}{l}\text { Parameter } \\
\text { N=645 }\end{array}$ & \% C CD + & \% T CD + & \% T CD3 + \\
\hline Males (Adults) & 42 & 24 & 72 \\
Females (Adults) & 43 & 32 & 72 \\
Males (Children) & 29 & 17 & 50 \\
Females (Children) & $34 * *$ & $22 * *$ & $61 * *$ \\
Smokers & 43 & 24 & 71 \\
No smokers & 43 & 24 & 74 \\
Stress & 44 & 25 & 74 \\
No stress & $42 *$ & 24 & $71 * *$ \\
Alcohol & 42 & 24 & 72 \\
No alcohol & 43 & 28 & 72 \\
\hline
\end{tabular}

$* p<0.05$ for the difference among data; $* * p<0.01$ for the difference among data

Lymphocyte values and geographical origin: We observed a differential pattern for absolute lymphocytes count according to the city of origin of blood donors. They had higher absolute CD3+ and CD4+ cells count in Ribeirão Preto and Porto Alegre (South/Southeast regions), intermediate count in Goiânia and Salvador (Midwest/Northeast regions) and lower in Belém (North region). The CD3+ T lymphocytes subsets were higher for donors from Ribeirão Preto, when compared with Salvador, Belém and Goiânia $(p<0.01)$. We also detected a significant difference comparing values for patients from Belém with those from Goiânia and Porto Alegre $(p<0.01)$ (Table 4).

CD3 + absolute cells count also was lower in Belém $(p<0.05)$ in comparison with any of other cities, but results were similar for Ribeirão Preto, Salvador, Porto Alegre and Goiânia. We observed the same pattern of variability for CD4+ T lymphocytes comparing values for donors from Ribeirão Preto, Salvador, Belém and Goiânia $(p<0.01)$. Again, these absolute values showed a significant difference between Belém and Porto Alegre $(p<0.01)$. The absolute values for CD8+T lymphocytes showed less variation. These results were statistically different when compared Belém (lower values) with Salvador, São Paulo city and Porto Alegre (higher values, $p<0.05$ ). Table 4 summarizes the values found for these T-cells subsets count.

\section{DISCUSSION}

The comparison of $\mathrm{T}$ lymphocytes in healthy and blood donors from distinct regions of Brazil, demonstrate that there are significant differences in these parameters, depending on the cell subsets evaluated, and the geographical origin of individuals. In a previous study we

Table 4

Absolute values for T lymphocytes (mean ( \pm standard deviation) according to the geographic origin of blood donors)

\begin{tabular}{|c|c|c|c|c|}
\hline City, State & $\mathrm{N}(645)$ & $\mathrm{T}$ CD $4+$ Cells $/ \mu \mathrm{L} / \mathrm{SD}$ & $\mathrm{T} \mathrm{CD} 8+$ Cells $/ \mu \mathrm{L} / \mathrm{SD}$ & $\mathrm{T} \mathrm{CD} 3+$ Cells $/ \mu \mathrm{L} / \mathrm{SD}$ \\
\hline Salvador, Bahia & 245 & $975 \pm 317$ & $572 \pm 239$ & $1641 \pm 500$ \\
\hline Belém, Pará* & 100 & $899 \pm 236$ & $472 \pm 170$ & $1473 \pm 387$ \\
\hline Goiania, Goiás & 100 & $937 \pm 272$ & $597 \pm 255$ & $1616 \pm 451$ \\
\hline Ribeirão Preto, São Paulo & 100 & $1155 \pm 434$ & $642 \pm 266$ & $1866 \pm 623$ \\
\hline Porto Alegre, Rio Grande do Sul & 100 & $1071 \pm 335$ & $609 \pm 245$ & $1751 \pm 508$ \\
\hline
\end{tabular}

*All comparisons between values obtained from Belem donors were significantly lower than those found in donors from other cities. 


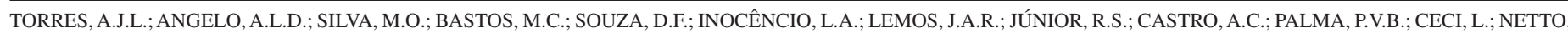
E.M. \& BRITES, C. - Establishing the reference range for T lymphocytes subpopulations in adults and children from Brazil. Rev. Inst. Med. Trop. Sao Paulo, 55(5): 323-8, 2013.

demonstrated that blood donors from North and Northeast states had a different range of normal variations for $\mathrm{CD} 3+, \mathrm{CD} 4+$ and $\mathrm{CD} 8+\mathrm{T}$ cells subsets. In the present work we compared these parameters for blood donors from cities of other different regions, and included children in two of them ${ }^{8}$.

The immune response usually is modulated according to different factors, like nutritional aspects, ethnicity, age, gender and others ${ }^{11,26}$. This may impact some specific aspects of the response against infections, for instance ${ }^{5,21}$. In addition, some available evidence suggest that nutritional factors like the amount of 3-omega, arginin, glutamine, proteins supplement, and nucleic acids in the food may help the immune system to produce a higher level of cytokines and other important factors for cell function ${ }^{4}$. Nutritional supplementation may enhance immune functions even for healthy individuals ${ }^{22}$.

Hematological parameters and T lymphocytes subsets are presented differently in literature, according to geographical area, economic level, age and nutritional status. Lower platelets and leukocytes values were reported in some studies realized with blood donors from Ethiopia, in comparison with standards from other regions ${ }^{12}$. In Italy, CD3 T absolute values showed a variation $3.7 \%$ higher than Turkey, and $1 \%$ than Sweden. For CD4+ T lymphocytes, these variations were $6 \%$ and $2.9 \%$, respectively, and for CD8+ T cells were $2.6 \%$ and $3.2 \%$, respectively ${ }^{16}$. $\mathrm{CD} 3+$ absolute $\mathrm{T}$ lymphocytes count in China was $0.4 \%$ higher, when comparing with Indian's values. For CD4+ and CD8+ T cells these results were $0.7 \%$ and $4.3 \%$ higher respectively ${ }^{18}$.

Although these variations are not wide, they can be significant when we use such parameters for taking clinical decisions. In HIV infections, for instance, a minimal difference can lead clinicians to start therapy or prophylaxis against opportunistic infections, since these recommendations are based on a specified range of CD4+ cells count.

Regarding reference levels for children, we found a wide variation in lymphocytes count and its subsets in this population. These findings are in conformity with the previous reports on hematological parameters in children ${ }^{1,33}$. We observed that the CD4+ T cells count was significantly higher in females than males, in accordance with the observed in adults. This observation was largely due to the higher levels of CD4+ cells in female children older than five years. This is in agreement with some studies in Asian and European children ${ }^{15,28}$. On the other hand, several studies in Africans showed no significant gender difference in the CD4+ cells count of children until adolescence, after which females tend to have higher number of CD4+ cells than males ${ }^{6,9}$. The reasons for this disparity are not clear but both genetic and environmental factors may play a role ${ }^{31}$.

The Brazilian population has a wide diversity per geographic region with unique nutritional, ethnics, and behavior characteristics. For instance, the African heritage in Salvador is very strong, and some costumes were well preserved, like dietary, music, and others. Most of Salvador's population (77.5\%) is composed by African descendents ${ }^{23}$. The South and North regions have less African influence, but a strong European and Amerindian presence, respectively ${ }^{17}$. Most of the Indian population are localized at North and Mid-West regions from Brazil, while in South and Southeast predominates the European influence. These findings can be associated with the different results found by $\mathrm{T}$ lymphocytes subsets among Brazilian cities in our study, and reinforce the importance of defining the regional variations for these parameters ${ }^{24}$.

Others variables can also influence the immune response. In our study, absolute $\mathrm{T}$ lymphocytes subpopulations values were higher in females when compared with males. These results are in accordance to other reports, and are a likely consequence of the effect of sexual hormones on the production and release of $\mathrm{T}$ lymphocytes in blood 22

Some life style characteristics like smoking, sleep time, and alcohol consumption can also exert an influence on the immune system ${ }^{23}$. Tobacco's complex has more than 4500 chemicals toxics substances. Tobacco's components had been used to modulate cellular immune response in vivo and in vitro experiments. An important condition potentially associated with immune response is the population's socioeconomic level. The Brazilian cities present a large variation in Human Development Index (HDI) level, which means they are likely to have different economic, nutritional, and stress characteristics. São Paulo, Rio de Janeiro, Rio Grande do Sul and Goiás states are among the most developed areas in country, with higher HDI levels, while Pará and Bahia are in the opposite side of HDI scale. These disparities may contribute to explain the difference in lymphocytes count we detected when comparing the mean values of $\mathrm{T}$ lymphocytes in these different areas. They are suggesting that higher HDI correlates with a higher absolute number of T-cells lymphocytes.

Currently, North American (USA) and European T lymphocytes reference ranges are used in Brazil. These reference values were defined by studies conducted by Becton Dickinson corporation (USA) ${ }^{5}$. For CD3+ T lymphocytes these median values are 1410 cells/ $\mu \mathrm{L}$ (reference interval 690-2540 cells/ $\mu \mathrm{L}$ ), for CD4+ T cells 880 cells/ $\mu \mathrm{L}$ (410-1590), and for CD8+ T lymphocytes 490 cells/ $\mu \mathrm{L}(190-1140)^{5}$. Our study found median values for T lymphocytes subsets in Brazilian population and suggest the need of local parameters for diagnostic and monitoring of HIV patients and/or others immunodeficiencies.

Defining the reference values of $\mathrm{T}$ cell count for Brazilian population is an important point, due to the wide variability in its characteristics, according to the country region. $\mathrm{CD} 4+$ and $\mathrm{CD} 8+\mathrm{T}$ lymphocytes are important markers of cellular immunodeficiency, and variation in the reference range may affect the clinical decision process. In children, these parameters are strongly influenced by factors like age, and it is of great importance to determine the limits of normality for these cells subsets in pediatric population.

Although the differences found in our study are not large enough to exclude the use of the current reference pattern, they are important to emphasize the regional variations, making possible for clinicians to more accurately define the real stage of immunodeficiency presented by our patients.

\section{RESUMO}

\section{Estabelecimento de valores de referências para subpopulações de linfócitos $\mathrm{T}$ em adultos e crianças no Brasil}

Os valores de referências de linfócitos T existentes no Brasil são baseados em dados originados de outros países. Não existem dados locais da variação normal para estes parâmetros em adultos e crianças 
TORRES, A.J.L.; ANGELO, A.L.D.; SILVA, M.O.; BASTOS, M.C.; SOUZA, D.F.; INOCÊNCIO, L.A.; LEMOS, J.A.R.; JÚNIOR, R.S.; CASTRO, A.C.; PALMA, P.V.B.; CECI, L.; NETTO, E.M. \& BRITES, C. - Establishing the reference range for T lymphocytes subpopulations in adults and children from Brazil. Rev. Inst. Med. Trop. Sao Paulo, 55(5): 323-8, 2013.

brasileiras. Avaliamos a variação normal encontrada em doadores de sangue de cinco grandes cidades brasileiras em diferentes regiões e em crianças residentes em Salvador e Rio de Janeiro. Todas as amostras foram processadas por citometria de fluxo. Os resultados foram analisados de acordo com região, gênero e estilo de vida dos doadores. Um total de 641 adultos (63\% homens) e 280 crianças (58\% meninos) participaram do estudo. Valores absolutos de CD3+ e CD4+ foram significantemente maiores no gênero feminino (adultos e crianças). Maiores valores de CD4+ em adultos foram associados com tabagismo, enquanto que maiores valores de CD8+ foram encontrados entre crianças do sexo feminino. Adultos das regiões sul e sudeste apresentaram maiores valores absolutos para todas as células $\mathrm{T}$ enquanto que adultos da região norte, apresentaram menores valores. Indivíduos residentes no nordeste e centro-oeste obtiveram contagens intermediárias para todas as populações de células T. Entretanto, estas diferenças entre as regiões, não demonstraram diferença estatística. No Brasil, gênero e tabagismo foram os principais determinantes para diferenças em valores de referências de linfócitos T.

\section{ACKNOWLEDGEMENTS}

AIDS and STD National Program from Brazilian Ministry of Health, Hematology and Hemotherapy Centers from Bahia, Pará and Ribeirão Preto, Central Laboratory from Goiás and Hospital Nossa Senhora da Conceição from Rio Grande do Sul.

\section{REFERENCES}

1. Anglaret X, Diagbouga S, Mortier E, Meda N, Verge-Valette V, Sylla- Koko F, et al. CD4+ T-lymphocyte counts in HIV infection: are European standards applicable to African patients? J Acquir Immune Defic Syndr Hum Retrovirol. 1997;14:361-7.

2. Antoine T, Heyraud A, Bosso C, Samain E. Highly efficient biosynthesis of the oligosaccharide moiety of the GD3 ganglioside by using metabolically engineered Escherichia coli. Angew Chem Int Ed Engl. 2005;44:1350-2.

3. Audu RA, Idigbe EO, Akanmu AS, Mafe AG. Values of CD4+ T lymphocyte in apparently healthy individuals in Lagos, Nigeria. Eur J Sci Res. 2007;16: 168-73.

4. Autran B, Carcelain G, Li TS, Blanc C, Mathez D, Tubiana R, et al. Positive effects of combined antiretroviral therapy on CD4+ T cell homeostasis and function in advanced HIV disease. Science. 1997;277:112-6.

5. Becton Dickinson Indústrias Cirúrgicas Ltda. Manual para quantificação de linfócitos T CD4 / CD8. 2006. p. 88-9.

6. Bisset LR, Lung TL, Kaelin M, Ludwig E, Dubs RW. Reference values for peripheral blood lymphocyte phenotypes applicable to the healthy adult population in Switzerland. Eur J Haematol. 2004;72:203-12.

7. Bofill M, Janossy G, Lee CA, MacDonald-Burns D, Phillips AN, Sabin C, et al Laboratory control values for CD4 and CD8 T lymphocytes. Implications for HIV-1 diagnosis. Clin Exp Immunol. 1992;88:243-52.

8. CEPAL. Comissão Econômica para América Latina. Emprego, desenvolvimento humano e trabalho decente: a experiência brasileira recente. Brasilia: CEPAL/PNUD/ OIT; 2008.

9. Chandra RK. 1990 McCollum Award lecture. Nutrition and immunity: lessons from the past and new insights into the future. Am J Clin Nutr. 1991:53:1087-101.

10. Denny T, Yogev R, Gelman R, Skuza C, Oleske J, Chadwick E, et al. Lymphocyte subsets in healthy children during the first 5 years of life. JAMA. 1992;267:1484-8.
11. Embree J, Bwayo J, Nagelkerke $\mathrm{N}$, Njenga S, Nyange $\mathrm{P}$, Ndinya-Achola J, et al. Lymphocyte subsets in human immunodeficiency virus type 1-infected and uninfected children in Nairobi. Pediatr Infect Dis J. 2001;20:397-403.

12. European Collaborative Study. Are there gender and race differences in cellular immunity patterns over age in infected and uninfected children born to HIV-infected women? J Acquir Immune Defic Syndr. 2003;33:635-41.

13. Fahey JL, Schnelle JF, Boscardin J, Thomas JK, Gorre ME, Aziz N, et al. Distinct categories of immunologic changes in frail elderly. Mech Ageing Dev. 2000;115:1-20.

14. Feki S, Rekaya Z, Ben Chaaben T, Zribi A, Boukef K, Jenhani F. Determination of T-lymphocyte subsets in a north African population (Tunisia): establishment of normal ranges and results in HIV-infected individuals. Dis Markers. 1998;14:161-4.

15. Gill GV, England A, Marshal C. Low platelet counts in Zambians. Trans R Soc Trop Med Hyg. 1979;73:111-2.

16. Hussain T, Abbas S, Khan MA, Scrimshaw NS. Lysine fortification of wheat flour improves selected indices of the nutritional status of predominantly cereal-eating families in Pakistan. Food Nutr Bull. 2004;25:114-22.

17. Instituto Brasileiro de Geografia e Estatística. Brasil: 500 anos de povoamento Brasilia: IBGE; 2000.

18. Lee B, Yap H, Chew F. Age- and sex-related changes in lymphocyte subpopulations of healthy Asian subjects: from birth to adulthood. Cytometry. 1996;26:8-15.

19. Levin A, Brubaker G, Shao JS, Kumby D, O'Brien TR, Goedert JJ, et al. Determination of T-lymphocyte subsets on site in rural Tanzania: results in HIV-1 infected and noninfected individuals. Int J STD AIDS. 1996;7:288-91.

20. Libamba E, Makombe S, Harries AD, Chimzizi R, Salaniponi FM, Schouten EJ. Scaling up antiretroviral therapy in Africa: learning from tuberculosis control programmes - the case of Malawi. Int J Tuberc Lung Dis. 2005;9:1062-71.

21. Lisse IM, Aaby P, Whittle H, Jensen H, Engelmann M, Christensen LB. T-lymphocyte subsets in West African children: impact of age, sex, and season. J Pediatr. 1997;130:77-85.

22. Maini MK, Gilson RJ, Chavda N, Gill S, Fakoya A, Ross EJ, et al. Reference ranges and sources of variability of CD4 counts in HIV-seronegative women and men. Genitourin Med. 1996;72:27-31.

23. Ndhlovu Z, Ryon JJ, Griffin DE, Monze M., Kasolo F, Moss WJ. CD4+ and CD8+ T-lymphocyte subsets in Zambian children. J Trop Pediatr. 2004;50:94-7.

24. Njoku MO, Sirisena ND, Idoko JA, Jelpe D. CD4+ T-lymphocyte counts in patients with human immunodeficiency virus type 1 (HIV-1) and healthy population in Jos, Nigeria. Niger Postgrad Med J. 2003;10:135-9.

25. Roller M, Rechkemmer G, Watzl B. Prebiotic inulin enriched with oligofructose in combination with the probiotics Lactobacillus rhamnosus and Bifidobacterium lactis modulates intestinal immune functions in rats. J Nutr. 2004;134:153-6.

26. Santagostino A, Garbaccio G, Pistorio A, Bolis V, Camisasca G, Pagliaro P, et al. An Italian national multicenter study for the definition of reference ranges for normal values of peripheral blood lymphocyte subsets in healthy adults. Haematologica. 1999;84:499-504.

27. Saxena RK, Choudhry V, Nath I, Das SN, Paranjape RS, Babu G, et al. Normal ranges of some select lymphocyte sub-populations in peripheral blood of normal healthy Indians. Curr Sci. 2004;86:969-75.

28. Scrimshaw NS, Sangiovanni JP. Synergism of nutrition, infection, and immunity: an overview. Am J Clin Nutr. 1997:66:464S-77S.

29. Siegel PD, Saxena RK, Saxena QB, Ma JK, Ma JY, Yin XJ, et al. Effect of diesel exhaust particulate (DEP) on immune responses: contributions of particulate versus organic soluble components. J Toxicol Environ Health A. 2003;67:221-31. 
TORRES, A.J.L.; ANGELO, A.L.D.; SILVA, M.O.; BASTOS, M.C.; SOUZA, D.F.; INOCÊNCIO, L.A.; LEMOS, J.A.R.; JÚNIOR, R.S.; CASTRO, A.C.; PALMA, P.V.B.; CECI, L.; NETTO, E.M. \& BRITES, C. - Establishing the reference range for T lymphocytes subpopulations in adults and children from Brazil. Rev. Inst. Med. Trop. Sao Paulo, 55(5): 323-8, 2013.

30. Sopori M. Effects of cigarette smoke on the immune system. Nat Rev Immunol. $2002 ; 2: 372-7$.

31. Telles E. Racismo à brasileira: uma nova perspectiva sociológica. Rio de Janeiro: Relume-Dumará/Fundação Ford; 2003.

32. Torres AJL, Angelo ALD, Netto EM, Sampaio GP, Souza DFC, Inocêncio LA, et al. Reference range for $\mathrm{T}$ lymphocytes populations in blood donors from two different regions in Brazil. Braz J Infect Dis. 2009;13:221-5.
33. UNAIDS. 2006 Report on the global AIDS epidemic. [cited 2007 Feb 2]. Available from: http://www.unaids.org/en/HIV_data/2006Global

34. World Health Organization. Scaling up antiretroviral therapy in resource-limited settings. Treatment guidelines for a public health approach. Geneva: WHO; 2005.

Received: 1 October 2012

Accepted: 11 March 2013 